\title{
INFLUENCE OF CULTIVATION OF CHLORELLA VULGARIS ON MICROORGANISMS IN SEAFOOD WASTEWATER
}

\author{
Nguyen Thi Dong Phuong1, ${ }^{1}$, Tran Thi Ngoc Thu ${ }^{1}$, Le Thi Van Anh ${ }^{2,4,5}$, Nguyen Huu Phuoc Trang ${ }^{3}$ \\ ${ }^{1}$ College of Technology, the University of Danang, Vietnam \\ ${ }^{2}$ Journal of Biotechnology, Publishing House for Science and Technology, Vietnam Academy of Science and \\ Technology, Vietnam \\ ${ }^{3}$ University of Nantes, Nantes, France \\ ${ }^{4}$ Graduate University of Science and Technology, Vietnam Academy of Science and Technology, Vietnam \\ ${ }^{5}$ National Key Laboratory of Gene Technology, Institute of Biotechnology, Vietnam Academy of Science and \\ Technology, Vietnam
}

${ }^{\square}$ To whom correspondence should be addressed. E-mail: dongphuongluan@gmail.com

Received: 17.11 .2016

Accepted: 30.6 .2017

\section{SUMMARY}

Microalgae cultivation in wastewater for many purposes has been investigated recently decade ago. In this study, Chlorella vulgaris was chosen to culture for examination of its influences on microorganisms of seafood wastewater in particular aerobic bacteria, Coliform and E. coli. The microalgae cultivation was realized in Erlenmeyer flasks containing seafood wastewater medium. Another was also grown in original medium called Sueoka medium for control. All experiments were set up until almost all Chlorella vulgaris decanted or flocculated in the bottom of flasks. The changes of bacteria counts including aerobic bacteria, Coliform and $E$. coli were measured to evaluate the impact of cultivation of Chlorella vulgaris on them in this sewage. Otherwise, the growth of microalgae has been also recorded for evaluating the effect of a new medium on metabolism of Chlorella vulgaris. The results showed that the bacteria counts were significantly reduced after day 3 of microalgae culture. These results have been calculated the efficiency of aerobic bacteria, Coliform and E. coli elimination out of wastewater medium represented approximately $70 \%, 81 \%$ and $90 \%$ respectively. These eliminations provided evidences of difficult metabolism of bacteria under the presence of microalgae as like as Chlorella vulgaris. In other words, the symbiosis of microalgae and bacteria in sewage could prevent the raising of bacteria counts.

Keywords: Algae cultivation, bacteria metabolism, biofuel production, microalgae potential, wastewater treatment

\section{INTRODUCTION}

For several years, it is well known that microalgae were cultivated as like as a good resource of many compounds such as certain pigments, lipids or polysaccharides. So far, microalgae were mainly used in aquaculture for the larvae and young shellfish feed, or for the production of molecules with high value added to the cosmetic and nutraceutical industries. Moreover, the application on sewage treatment of microalgae has been also contributed to improved conventional ways. US researchers Oswald and Golueke in 1960, proposed the use of microalgae in wastewater treatment, via the conversion of biomass into biogas (methane) by the fermentation process (Oswald, Golueke, 1960).

For regulatory, economic and environmental reasons, companies are increasingly concerned by the reduction of the environmental footprint of their activities. This trend has led to the advancement of much research in the field of industrial effluents and more particularly water processes treatment. The microalgae appearance has emerged as a solution in context of environmental sustainability. Indeed, they could help to effectively remove nutrients in high concentrations in wastewater, with the second advantage to produce biomass that can be used as feedstock for biofuel production. Samori and his 
colleagues at the University of Bologna, Italy carried out the growth and nitrogen removal capacity of Desmodesmus communis and of a natural microalgae consortium in a batch culture system in view of urban wastewater treatment (Samori et al., 2010). Their result reached was almost $100 \%$ for ammonia and phosphorous removal at any N/P ratio characterizing the wastewater nutrient composition.

On the other hand, wastewater treatment in conjunction with biofuel production has been a domain with the most plausible commercial application in short term. Microalgae enhance the removal of nutrients, organic contaminants, heavy metals, and pathogens from domestic wastewater and an interesting raw material for the production of high-value chemicals (algae metabolites) or biogas (Muñoz, Guieysse, 2006; Bowman, Thomae, 1961; Blasco, 1965; Cole, 1982). The bacterial system exists in wastewater still high level before and after water treatment. Many bacteria could pollute to any environment if they have been.

Microalgae have got attention to researchers because of many advantages. They contain many organic compounds such as carbohydrates, proteins, high lipids for biofuel production, a nutritional supplement and for oil high in the omega -3 fatty acid DHA etc. Meanwhile, microalgae cultivation has used sunlight, $\mathrm{CO}_{2}$ and inorganic salts for growth (Christi, 2007). Therefore, microalgae could be used in wide purpose of applications as biofuel production, fertilizer, nutraceuticals, green production, wastewater treatment etc. (Brennan, Owende, 2010). Because of wastewater treatment purposes, bacteria would be surveyed for influence on microalgae growth.

\section{MATERIALS AND METHODS}

\section{Experimental set-up}

Chlorella vulgaris (C. vulgaris) was purchased from the cultivation collection of GEPEA laboratory (belongs University of Nantes, France) and cultivated in Erlenmeyer flasks of $2 \mathrm{~L}$ with the original Sueoka medium to concentration of 1 g. $\mathrm{L}^{-1}$. This medium has described in table 1 (Brennan, Owende, 2010; Harris, 2009).

Then microalgae were adjusted in other flasks of $2 \mathrm{~L}$ at the initial concentration of $0.01 \mathrm{~g}$. $\mathrm{L}^{-1}$ with continuous aeration mode. This concentration was initially investigated to this article's study while other concentrations would be set up in continuous series for another one. Two media for algae cultivation were established: one with original Sueoka medium, and another one with secondary effluent of wastewater (Centrate) of the seafood's factory (target medium) to evaluate the algal and microorganism growth. The centrate was collected directly from the seafood's factory named Tho Quang, industry zone of Danang city. However, bacteria count of centrate have not only been measured before adjusting microalgae but also done during experiments. The experiments were realized until the decantation of microalgae strain in the bottom of flasks.

During the culture, algae were harvested daily just the three tests of cell calculating, optical density at $682 \mathrm{~nm}\left(\mathrm{OD}_{682}\right)$ and microorganism culture (microorganism inoculation). These tests were finished until cells of Chlorella vulgaris has been constant or algae $\mathrm{OD}_{682}$ has not changed.

\section{Analysis}

Cell concentration (biomass dry weight) of Biomass dry weight was determined by gravimetry. The sample was filtered through a rinsed glass fiber filter (Whatman GF/F), pre-dried and weighed. The filter was dried for $24 \mathrm{~h}$ at $105^{\circ} \mathrm{C}$, cooled in a desiccator, and weighed again.

Table 1. Ionic composition of the Sueoka culture media $\left(\mathrm{mg}^{\mathrm{L}} \mathrm{L}^{-1}\right)$.

\begin{tabular}{|c|c|c|c|c|c|c|c|c|c|c|}
\hline & $\mathrm{Na}^{+}$ & $\mathrm{K}^{+}$ & $\mathrm{NH}_{4}{ }^{+}$ & $\mathrm{Mg}^{2+}$ & $\mathrm{Ca}^{2+}$ & $\mathrm{Cl}^{-}$ & $\mathrm{NO}_{3}{ }^{-}$ & $\mathrm{HCO}_{3}{ }^{-}$ & $\mathrm{SO}_{4}{ }^{2-}$ & $\mathrm{PO}_{4}{ }^{3-}$ \\
\hline $\begin{array}{l}\text { Sueoka } \\
\text { based }{ }^{(*)}\end{array}$ & 230 & 28,7 & 243,9 & 13,8 & 6,8 & 493,1 & - & 610 & 54,6 & 69,8 \\
\hline
\end{tabular}


Microorganism inoculation was established to determine concentration for evaluating their growth under the presence of $C$. vulgaris. In order to determine the aerobic bacteria counts in a unit volume of centrate containing algae, a volume of 1 $\mathrm{mL}$ solution was collected and then diluted for inoculating on plates containing special medium. These plates were incubated at $37^{\circ} \mathrm{C}$ in 24 hours. Meanwhile Coliform and E. coli count was directly determined on petrifilm. The bacterial number was definitely determined by method of Reed and Muench (Reed, 1938). All of experiments were performed three folds for calculating the error bars (Altman, Bland, 2005).

For evaluating the efficiency of bacteria removal, the results were recorded daily and were focused on the values of bacteria concentration at the first day of microalgae inoculation in wastewater and in the final day of experiment. The formula of this efficiency was illustrated as follows:

$$
\mathrm{Eff}=\left(\frac{C_{o}-C_{n}}{C_{o}}\right) \times 100 \%
$$

In that:

$\mathrm{C}_{\mathrm{o}}$ : concentration of bacteria at the first day of microalgae inoculation, CFU.mL ${ }^{-1}$

$\mathrm{C}_{\mathrm{n}}$ : concentration of bacteria at the final day of experiment, CFU.mL ${ }^{-1}$

\section{RESULT AND DISCUSSION}

\section{The growth of microalgae}

To evaluate the growth of $C$. vulgaris in seafoodwastewater medium, this strain was cultivated in both two mediums, the one was original medium - Sueoka medium and the second was concentrate. Parameter of its growth was determined by $\mathrm{OD}_{682}$, Chlorophylle a or cell count were analyzed. The results were obtained from all of three parameters similarly on the graph. Therefore, the following graph (Fig 1) was represented for one of these three parameters.

The results showed that the growth of $C$. vulgaris in new medium characterized centrate medium appeared normal as like as rule of algae growth (the algae growth has four phases adduced in Figure 1.) but had a little difference at phase stabilization. Microalgae in concentrate have significantly increased to maximum of number of cell of $1.15 \mathrm{E}+06$ correspond with value of $\mathrm{OD}_{682}$ of 1.564 on days 9. While $C$. vulgaris grown in Sueoka medium at level low than in concentrate on day 8 . However, the growth of microalgae in Sueoka medium could has been more stable than in concentrate. Evidently, microalgae in concentrate reached in death more rapidly than another. By day 14, cells of $C$. vulgaris could stop duplicating because they absorbed nutrients of concentrate to conduct stress on cell. Moreover, the presence of bacteria in medium could conduct an important decrease. This has also been mentioned the contamination with bacteria is a serious problem for algae culture (Muñoz, Guieysse, 2006; Bowman , Thomae, 1961; Richard, 1965; Cole, 1982). Most of microalgae could decant to the bottom of flask.

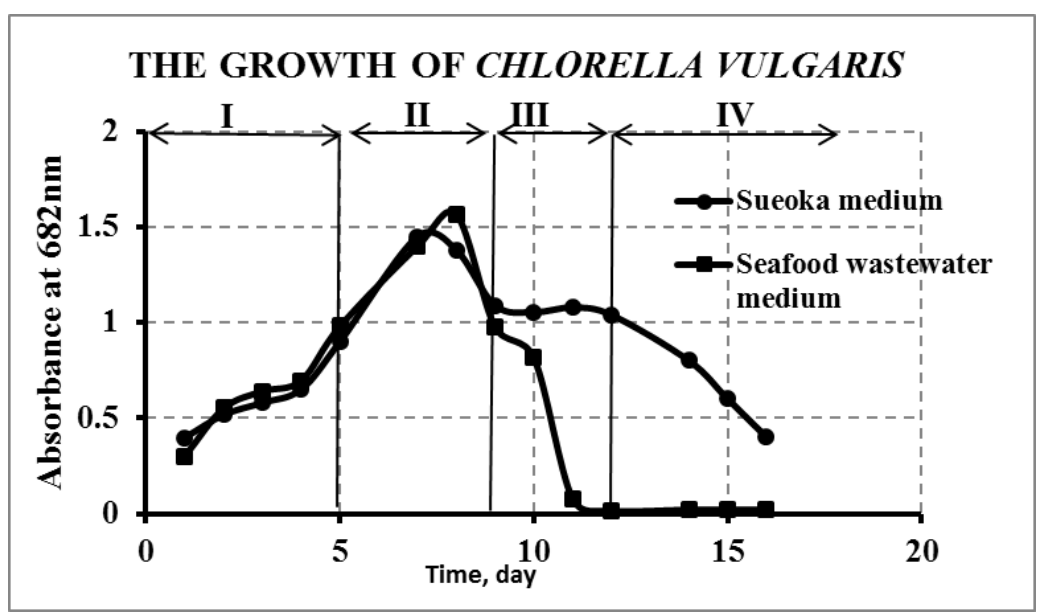

Figure 1. The growth of $C$. vulgaris in two medium: Sueoka medium and seafood wastewater medium with standard error of charts at $0.1 \%$ 
Influence of microalgae on bacterial growth

As determination of algae growth in wastewater, bacteria in wastewater were also analyzed concentration before and during adjusting microalgae.
It was clear that bacterial counts gradually decreased over time. The aerobic bacteria counts reduced from 2.4E+08 CFU/mL to $0.8 \mathrm{E}+08 \mathrm{CFU} / \mathrm{mL}$ at day 14 . These results showed in Figure 2.

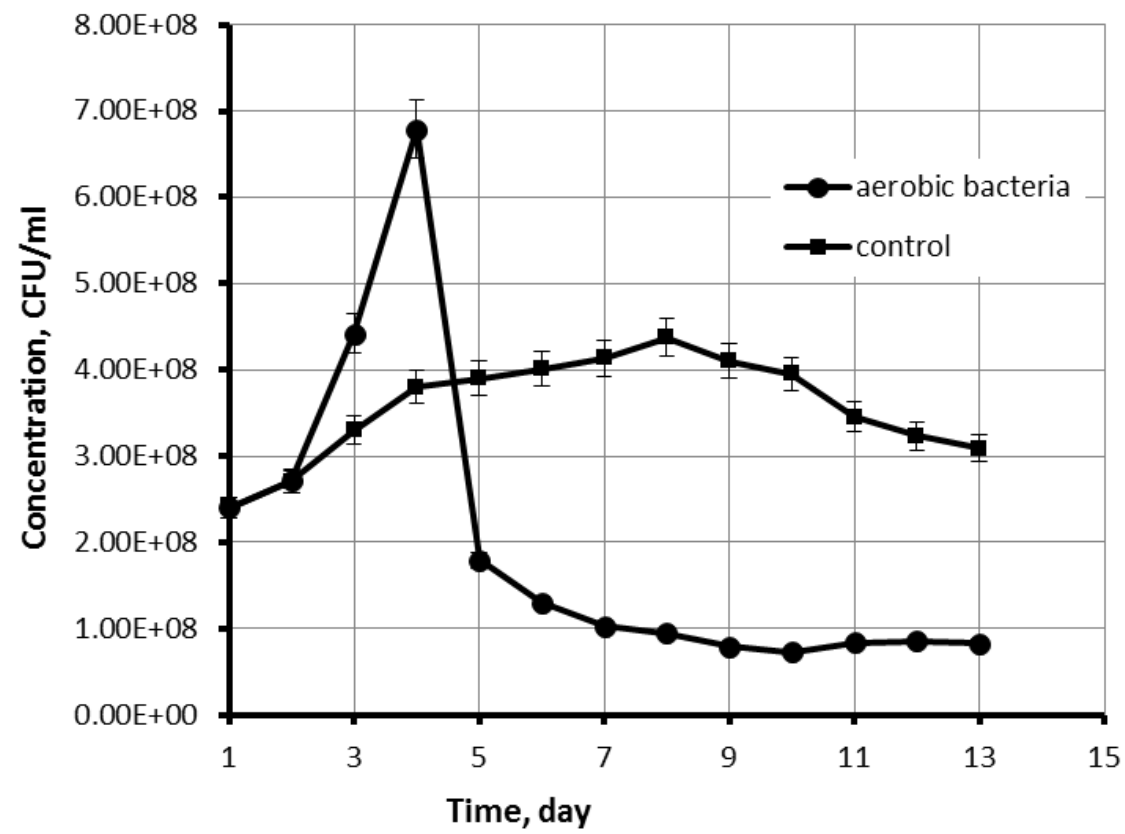

Figure 2. The growth of aerobic bacteria in concentrate with $C$. vulgaris, with the standard error of the aerobic bacteria chart at $0.9 \%$ and of the control chart at $5 \%$.

In Figure 2, bacteria in concentrate with microalgae increased rapidly to day 4 and just reached maximum concentration of $6.8 \mathrm{E}+08$ $\mathrm{CFU} / \mathrm{mL}$ on this day. However, their concentration gradually declined to $0.8 \mathrm{E}+08$. The result was also carried out that bacterial counts in concentrate with microalgae fell sharply than in control. This could be expressed that after day 5, the nutrient of inoculum medium lead to be nearly exhausted. Moreover, the bacteria could be competing with microalgae for resource of nutrition. However, their increase to maximum counts in concentrate with algae has been many times higher than in control, suggesting that the presence of microalgae in concentrate supplied oxygen for bacterial inoculum. In other words, the increase of microalgae cell density would release oxygen which is required for bacteria growth.

For Coliform and E. coli, the results showed are almost identical to the aerobic bacteria in Figure 3 .

Figure 3 carried out a type of graph. There was a dramatically decrease of Coliform counts after day 3 .
However, they were clearly found more in control, suggesting Coliform grew rapidly unless microalgae were present.

In Figure 4, the results also showed the similarities unless the points of control graph. The $E$. coli growth increased slightly more than in control.

The results were obtained in Figures 3 and 4 indicating a similarity of Coliform comportment also $E$. coli. Their growth was strong under the presence of microalgae at the first day. After day 3, the bacterial counts were reduced significantly in concentrate with microalgae. These suggests that the bacteria competed for nutrients with microalgae for their growth. However, the growth of microalgae could cause bacteria to weaken as the days after. $C$. vulgaris was still raising concentration to maximum on the day 9. This could carry out an opposite result which showed that the presence of bacteria would cause to contaminate to microalgae (Borde et al., 2003). 


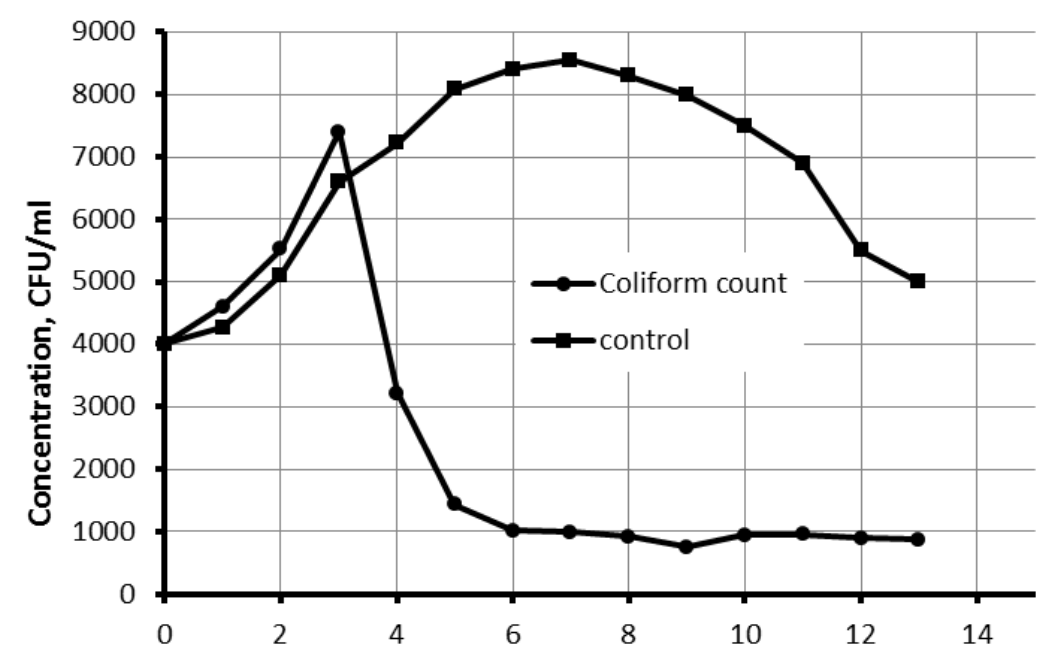

Figure 3. The growth of Coliform in concentrate with C. vulgaris, with the standard error of the Coliform count chart at $0.5 \%$ and of the control chart at $1.2 \%$.

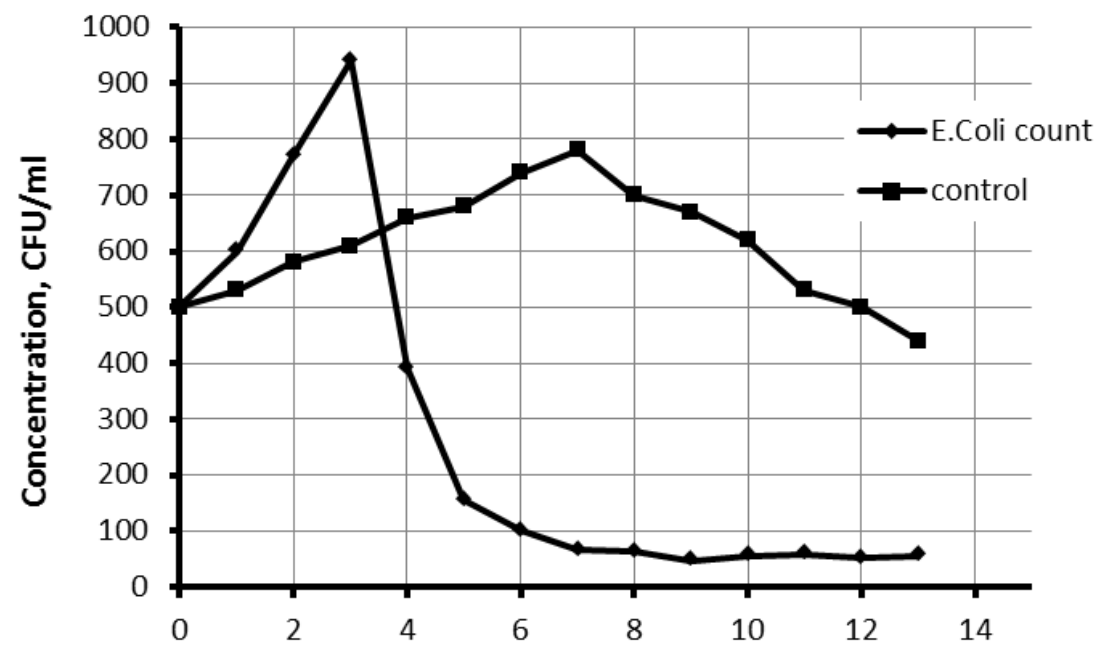

Figure 4. The growth of E. coli in concentrate with C. vulgaris, with the standard error of the E. coli chart at $1.0 \%$ and of the control chart at $2 \%$

\section{CONCLUSION}

The microalgae cultivation has clearly influenced the growth of bacteria. This study carried out the results that identified the changes in concentration of bacteria during adjusting $C$. vulgaris. Microalgae could obstruct to the metabolism of bacteria and weaken them to eliminate out of nutrient medium. These results showed clearly on Figures, bacteria could not raise the counts of aerobic bacteria, Coliform and E. coli after obtaining the maximum at $6.8 \mathrm{E}+08 \mathrm{CFU} / \mathrm{ml}$, $7400 \mathrm{CFU} / \mathrm{ml}$ and $940 \mathrm{CFU} / \mathrm{ml}$ respectively at the same day 3. After that, the decline in counts was starting to the end of experiments at day 14. From that, the efficiencies of aerobic bacterial, Coliform and E. coli elimination out of concentrate were calculated approximately $70 \%, 81 \%$ and $90 \%$ respectively. These results would have provided a suggestion for efficient treatment process of 
wastewater by microalgae culture. Most of bacteria have been eliminated out of wastewater medium by the growth of $C$. vulgaris.

Author contributions: All authors have studied and agreed to the final manuscript.

Acknowledgement: The authors thank to French Professors (PhD's Prof., GEPEA, University of Nantes, France) and colleague in the college of technology - UD for their contribution to advices, guides and strains.

\section{REFERENCES}

Bowman R, Thomae FW (1961) Long-Term Nontoxic Support of Animal Life with Algae, Science. 134(3471): $55-6$

Christi Y (2007) Biodiesel from microalgae, Biotechnol Adv 25: 294-306.

Brennan L, Owende P (2010) Biofuels from microalgae are view of technologies for production, processing, and extractions of biofuels and co-products., Renewable \& Sustain Ener Rev14: 557-577.

Cole JJ (1982) Interactions between Bacteria and Algae in Aquatic Ecosystems, Annual Review of Ecology and Systematics 13: 291-314. DOI: 10.1146/annurev.es. 13.110182.001451
Douglas G Altman, J Martin Bland (2005) Standard deviations and standard errors, the BMJ 331(7521): 903.

Harris EH (2009) The Chlamydomonas source book. Introduction to Chlamydomonas and its laboratory use. New York, Academic Press.

Hutner SH, Provasoli L, Schatz A, Haskins CP. (1950) Some approaches to the study of the role of metals in the metabolism of microorganisms. Proc Amer Philosophic Soc 94: 152-170.

Muñoz R, Guieysse B (2006) Algal-bacterial processes for the treatment of hazardous contaminants: a review, Water Res 40(15): 2799-815.

Oswald WJ, Golueke CG (1960) Biological transformation of solar energy. Adv Appl Microbiol 2: 223-262.

Blasco RJ (1965) Nature and Role of Bacterial Contaminants in Mass Cultures of Thermophilic Chlorella pyrenoidosa, Appl Microbiol 13(3): 473-477

Samori G, Samori C, Pistocchi R (2010) Growth and nitrogen removal capacity of Desmodesmus communis under different hydraulic retention times of a small scale semi-continuous system in view of urban wastewater treatment, Part II.

Borde X, Guieysse B, Delgado O, Munoz R, Hatti-Kaul R, Nugier-Chauvin C, Patin H, Mattiasson B (2003) Synergistic relationships in algal-bacterial microcosms for the treatment of aromatic pollutants. Bioresour Technol 86: $293-300$ 